\title{
Empowerment of Community Economic Independence Through Utilization of Local Potential
}

\author{
$1^{\text {st }}$ Sri Endah Indriwati \\ Biology Department, FMIPA \\ State University of Malang \\ Malang, Indonesia \\ sri.endah.fmipa@um.ac.id
}

\author{
$2^{\text {nd }}$ Eko Sri Sulasmi \\ Biology Department, FMIPA \\ State University of Malang \\ Malang, Indonesia
}

\author{
$3^{\text {rd }}$ Sulisetijono \\ Biology Department, FMIPA \\ State University of Malang \\ Malang, Indonesia
}

\begin{abstract}
The people of Malang Regency, especially in Poncokusumo sub-district, have diverse local potential and abundant. However, viewed from the knowledge and awareness of the local community has not shown the effort in economic growth. Strategies to overcome problems in managing local potentials require systemic, holistic, and dynamic constructive efforts from University as agents of science and technology to participate in the realization of a prosperous society. Implementation of community service used the methods of training, practice, and monitoring. Community economic empowerment implemented from March to July 2018. Prior knowledge regarding the potential utilization of local communities to improve the economic well-being explored through interviews and questionnaires, while the change of knowledge and skill after community service activities were measured using a sheet of questions and observation sheet performance. Overall there is increasing knowledge and skills gained by the community through community service activities.
\end{abstract}

Keywords: empowerment of economic independence, local potential

\section{INTRODUCTION}

Poncokusumo District is one of the areas located in Malang regency [1]. The potential of both natural resources and human resources needs to be constantly developed for the community prosperity. Some potential medicinal plants, food crops and crops, fruit crops, smallholder plantations, the flower sector and the spice and medicinal plants sector are easily found in Poncokusumo as local potentials [2], [3].

The abundance of the natural resource that used as superior products and home industries, in fact, has not been matched by the maximum effort of the village community. The home industry center is only found in certain hamlets. The inequality of developing the problem of home industry can be attributed to the fact about the low education background[4]. The lack of community understanding of a program has an impact on people's creativity and innovation in managing local potentials [5].
Strategies to overcome problems in managing local potentials require systemic, holistic, and dynamic constructive efforts from University as agents of science and technology to participate in the realization of a prosperous society. Empowerment efforts can be pursued through the synergy of local government districts with University in the form of dedication to the community whose implementation can involve students who are conducting real work college and in the completion of the final task. In this case, the lecturer acts as the originator of ideas, concepts of problem solving, assisting students and society. Students play a role in following up initiated programs through creative and innovative efforts whose implementation can be incorporated into real work college programs.

Community empowerment today is one of the main strategy of poverty alleviation program for Sustainable Development Goals (SDGs) [6]. Efforts of empowerment are taken because the approach of individual human development is absolutely necessary for the direction of socio-economic independence of the community. Socio-economic independence can be seen from the knowledge and awareness of the regional socio-economic potential, while its territorial range can start from the village as the smallest legal community institution.

Empowerment of economic independence community can be done with providing knowledge and skills to the community through counseling, training, and local potential utilization practices. So, the objective of this rsearch is foe implement community economic empowerment by training, practice, and monitoring in Poncokusumo, Malang

\section{METHOD}

Community economic empowerment implemented from March to July 2018. Implementation of community service used the methods of training, practice, and monitoring. The target of devotion is all of the housewives, but only 25 housewives of Argosuko village, Poncokusumo district present. 
Prior knowledge regarding the potential utilization of local communities to improve the economic well-being explored through interviews and questionnaires, while the change of knowledge and skill after community service activities were measured using a sheet of questions and observation sheet performance. The results and outcomes (knowledge and skills) of community service activities are analyzed descriptive qualitative [7].

\section{RESULTS AND DISCUSSION}

\section{A. Results of Community Knowledge Analysis on Utilization} of Local Potential

The result of community knowledge analysis about the utilization of local potential before community service activity shows that people in Argosuko Village, Poncokusumo district, Malang Regency: 1) have not utilized all available crop potential in environment as economic source, if it exists only part of society which uses for daily life, such as plants of the Zingiberaceae tribe in fresh condition (wet simplisia ) as a cooking spice ; 2) not yet know how to make dry simplisia ; 3) does not care about the existence of local potential crop of medicinal potential; 4) knowledge of beverage/food production has not cared to hygiene requirements; 5) has not demonstrated creativity and innovation in making artwork products made from local potential; and 6) have not utilized local potential crops as cultivation products.

This situation is not in line with the abundant local potential condition studied by Indriwati [4]. The high local potential wealth in Poncokusumo, Argosuko, can be developed became economical product value, such as 1) artwork (coconut, kelobor, banana stem, bamboo, and various household wastes), 2) healthy drinks and food (starfruit, cashew, apple, bark, etc.) 3) provision of seeds (sunflower, moringa, aloe vera), and 4) crop cultivation products (sunflower seed, moringa leaf, moringa, jelly, aloe vera leaves).

In order to increase public knowledge about utilization local potentials as described above, and to help facilitate the understanding of the community, the educational strategy on the local potential of economic value can be done verbally accompanied with videos, training, and practice. Furthermore, to see the changes that occur in the community carried out monitoring at the end of community service activities.

Results of monitoring after doing counseling, training, and practice indicates an increase in 1) knowledge of utilizing local potential as an economic source by $72 \%$ (from $20 \%$ to $92 \%$ ); 2) knowledge of making simplisia by $76 \%$ (from $4 \%$ to $80 \%$; 3) awareness of the existence of the local potential medicinal plants by $88 \%$ (from $8 \%$ to $96 \%$ ); 4) knowledge of the production of noodle / hygienic food by $68 \%$ (from $16 \%$ to
$84 \%)$; 5) creativity and innovation in making art products made from the local potential by $60 \%$ (from $8 \%$ to $68 \%$ ) ; and 6) local crop potential use as a cultivation product by $44 \%$ (from $32 \%$ to $76 \%$ ).

The findings of the monitoring results show that the 'level of public awareness' of the existence of medicinal plants is the highest. This means that people who originally did not know about the potential of medicinal plants now understand, but in the utilization as a product of cultivation has not been maximized. This is understandable because the community generally has limited land, and as a consequence, people only plant certain types of plants for daily needs. This limited land condition should not be the main reason for the community not to cultivate various types of local crops with economic potential. It becomes a challenge because people can cultivate crops among other growing plants that they usually plant [8], [9].

Another finding of monitoring activities is that the making of community simplisia increases by $80 \%$, meaning that not all targeted communities are able to make simplisia correctly. This can be explained because the knowledge of the harvest of simplisia material has not been mastered properly and correctly. The knowledge society is still limited to simple knowledge passed down by his ancestors, has not been studied scientifically, and not to use standardized harvesting the bulbs in terms of right [10], [11].

Public knowledge about the production of beverages and food hygiene increased by $68 \%$, meaning that now of all communities have the right knowledge about hygienic requirements. Public knowledge about the hygiene product requirements before getting counseling is still lacking, such as putting beverage/food products openly before packing, not using masks when packing, and not sterilizing the hands before working. The condition of the hygienic beverage/food product, after being tested in Microbiology Laboratory of Universitas Negeri Malang, shows this condition need to be used as a reflection for beverage/food entrepreneurs because the products after two weeks produced were showing the existence of microbe pollutants. This fact is contrary to the manufacturer's information that the drinks/manufactured foods have the endurance for up to 3-5 months.

\section{B. Results of Community Skills Analysis on Utilization of Local Potential}

In relation to the improvement of people's skills to produce artwork and cultivation, the effort is to provide training and practice [12], [13]. Training performed twice, while the practice is carried out in five times.

The results are achieved, there is an increase in community skills in making art products made from the local potential economic value by $60 \%$ (from $8 \%$ to $68 \%$ ). This indicates an 
increase, although not entirely because building that skill requires habits and talents. Skills require training and basic skills that everyone has [14]. Notoadmodjo says skills are applications of knowledge so that one's skill level is related to the level of knowledge, and knowledge is affected by the level of education, age, and experience [15]. While the factors that can affect skills directly according to Widyatun, namely motivation, experience, and expertise. So it can be concluded that the need for knowledge, experience, and motivation for improving skills [16].

\section{CONCLUSIONS}

Community empowerment through the utilization of local potential can increase the knowledge of society in the case of 1) knowledge of utilizing local potential as an economic source; 2) knowledge of making simplistic ; 3) awareness of the existence of the local potential medicinal plants; 4) knowledge of the production of noodle / hygienic food 5) creativity and innovation in making art products made from the local potential 6) local crop potential use as a cultivation product. Overall the increased knowledge and skills gained by the community through community service activities can be realized because of the synergy between government village, district, county and college, and the results can be used as authorized modal to increase the living standards towards economic independence.

Empowerment of Economic Independence Community through Utilization of Local Potential cannot be done instantly, it takes intense time and continuous monitoring. An ongoing process to empower the community toward economic independence needs to be based on the high devotion spirit and togetherness of the various parts. Empowerment of community economic independence will help the government programs to increase the economic independence of the community, if the strategy design used is implemented simultaneously and synergistically.

\section{REFERENCES}

[1] Pemkab Malang, 'Profil Kecamatan Poncokusumo', Profil Kecamatan Poncokusumo, 2017. [Online]. Available: http://poncokusumo.malangkab.go.id/pd/. [Accessed: 19-Dec-2019].

[2] S. E. Indriwati, E. S. Sulasmi, S. R. Lestari, B. Priambodo, H. Baidlowi, and L. Fanani, 'Pendampingan Desa Mandiri Dalam Strategi Branding Simplisia Potensi Lokal Kemasan Produk Guna Meningkatkan Kesejahteraan Masyarakat Kecamatan Poncokusumo', Jurnal KARINOV, vol. 2, no. 3, pp. 185-190, Nov. 2019.
[3] N. Baladina, R. Anindita, R. Isaskar, and S. Sukardi, 'Identifikasi Potensi Komoditi Pertanian Unggulan Dalam Penerapan Konsep Agropolitan Di Kecamatan Poncokusumo, Kabupaten Malang', Agricultural SocioEconomics Journal, vol. 13, no. 1, p. 30, Feb. 2016.

[4] S. E. Indriwati, Keanekaragaman Tanaman Obat di Kawasan Taman Nasional Bromo Tengger Semeru. Malang: UM Press, 2015.

[5] S. E. Melina, R. N. Pratiwi, and M. Hadi, 'Implementasi Kebijakan Program Peningkatan Keberdayaan Masyarakat (Ppkm) Berbasis Rumah Tangga Miskin (RTM) Di Kabupaten Malang (Studi Pada Desa Pandansari Kecamatan Poncokusumo Kabupaten Malang)', Jurnal Administrasi Publik (Jap), vol. 1, no. 5, pp. 872-880, 2013.

[6] I. Ishatono and S. T. Raharjo, 'SUSTAINABLE DEVELOPMENT GOALS (sdgs) DAN PENGENTASAN KEMISKINAN', Share : Social Work Journal, vol. 6, no. 2, p. 159, Dec. 2016.

[7] Sugiyono, Metode Penelitian Kombinasi (Mixed Methods). Bandung: Alfabeta, 2015.

[8] N. P. S. Dwiratna, A. Widyasanti, and D. N. Rahma, 'Pemanfaatan Lahan Pekarangan dengan Menerapkan Konsep Rumah Pangan Lestari', Dharma Karya: Jurnal Aplikasi IPTEKS untuk Masyarakat, vol. 5, no. 1, pp. 19-22, 2016.

[9] S. Ashari and T. B. Purwanti, 'Potensi dan Prospek Pemanfaatan Lahan Pekarangan untuk Mendukung Ketahanan Pangan', Forum Penelitian Agro Ekonomi, vol. 30, no. 1, pp. 13-30, 2012.

[10] Depkes RI, Cara Pembuatan Simplisia. Jakarta: Ditjen POM Departemen Kesehatan RI., 1985.

[11] Herawati, Nuraida, and Sumarto, Cara Produksi Simplisia Yang Baik. Bogor: Seafast Centre, 2012.

[12] N. Qomariah, 'Pemberdayaan Masyarakat Desa Melalui Pengembangan " Soft Skill Pembuatan Krupuk Samiler" Dalam Upaya Peningkatan Pendapatan Keluarga Di Kabupaten Bondowoso', Jurnal Pengabdian Masyarakat IPTEKS, vol. 1, no. 2, Nov. 2016.

[13] R. A. Kartikakirana and D. P. Agustina, 'Pengembangan Ekonomi Berbasis Potensi Lokal Untuk Pemberdayaan Masyarakat Di Dusun Banaran, Sumberagung, Jetis, Bantul', Prosiding Seminar Hasil Pengabdian MasyarakaT, vol. 1, no. 1, pp. 241-246, Nov. 2018.

[14] A. Iverson, Welcome To Reading. New York: World Book, 2001.

[15] S. Notoadmodjo, Metodologi Penelitian Kesehatan. Jakarta: Rineka Cipta, 2007.

[16] Widyatun, Ilmu Perilaku. Jakarta: Rineka Cipta, 2005. 